\title{
"Our Ancestors that We Carry on Our Backs": \\ Restaging Hawai'i's History in the Plays of \\ Victoria Nalani Kneububl
}

Diana Looser

\footnotetext{
$\mathrm{D}$
} uring the past twenty years, Victoria Nalani Kneubuhl has become established as one of Hawai'i's foremost playwrights, and arguably one of the most accomplished and politically efficacious dramatists working in the contemporary Pacific. Born in Honolulu in 1949 of Hawaiian, Samoan, and Caucasian descent, Kneubuhl received formal training as a playwright at the University of Hawai'i at Mānoa, where she received her MA in theatre and drama in 1987 . She has also made important contributions to local museum education as a living history interpreter and education coordinator at the Hawai'i Mission Houses Museum and the Judiciary History Center of Hawai'i. In the course of her career, Kneubuhl has produced over a dozen plays, as well as films, screenplays, and a novel, and has been the recipient of several honors, most notably the Hawai'i Award for Literature in I994 and the Elliot Cades Award for Literature in 2006.

A dominant theme in Kneubuhl's oeuvre is a critical examination of Hawai'i's colonial past, tracing instances of indigenous cultural loss and dispossession and offering possibilities for cultural restoration and renewal. Here, I discuss six plays written throughout Kneubuhl's career that are set in Hawai'i and treat particular events in Hawai'i's history. In selecting these works, I make a distinction between two broad genres of theatrical performance arising from Kneubuhl's training and work experience. The first genre is historical "plays for the theatre," which incorporate fictional or fantastic elements and are designed for repeated performance within the aesthetic and commercial frame of amateur or professional theatre production. The second is "living history programs," performances that have a stricter pedagogical purview and a tendency toward a more

The Contemporary Pacific, Volume 23, Number I, 73-104

(C) 201 I by University of Hawai'i Press 
realist style of presentation; these are based more directly on documentary sources, are usually developed in consultation with historians under the auspices of a museum or historic site, encourage community participation, and are designed for performance at a specific place and time and for a particular purpose. ${ }^{1}$ I consider three published examples of Kneubuhl's plays for the theatre: The Conversion of Ka'ahumanu (I988), Emmalehua (1986, revised 1996), and Ola Nā Iwi (1994); and three produced but unpublished living history programs, devised in order to commemorate the centennial of key events in the period covering the fall of the Hawaiian monarchy and the annexation of the Hawaiian Islands by the United States: "January, I 893" (I993), "Trial of a Queen: I 895 Military Tribunal" (I995), and "Ho“ohui “Āina: The Annexation Debate" (I998). ${ }^{2}$

In adopting a survey approach rather than a close reading of a single text, this discussion aims to provide a broad view of the themes and dramaturgical strategies in Kneubuhl's historiographic dramas, as well as an investigation of the varied uses of performance in helping to construct indigenous histories. Kneubuhl's history plays and programs undertake important cultural work in their interrogation of dominant colonial articulations of Hawai'i's history and in their enactment of alternative narratives that privilege Native Hawaiian viewpoints and communicative modalities, offering, through theatrical performance, "not only a rethinking of history's content but also a reworking of its axiomatic forms" (Gilbert and Tompkins I996, I08). By foregrounding "history" as a malleable, contestable, and open-ended discourse; exposing the political processes involved in the development of dominant representations of Hawai' $i$ and Native Hawaiians; and reexamining unresolved issues central to Hawaiian identities in the present, Kneubuhl's works of the past two decades have had an important ethical, social, and political role to play in the ongoing reassertion of Hawaiian culture, identity, and self-determination.

Kneubuhl's career as a popular playwright and a museum educator has been enabled by, and has contributed to, a series of social and intellectual developments. Her work can be situated in the context of the "Hawaiian Renaissance," a movement beginning in the I970s and marked by a renewed commitment to the preservation and promotion of kanaka maoli (Native Hawaiian) culture, history, and language, and by more assertive forms of political activism to secure recognition of indigenous rights. During the same period, the influence of feminist discourses had a marked impact on Kneubuhl's interest in women's histories and feminist theatre techniques. Coeval with the more widespread development of postcolo- 
nial theatre throughout Oceania since the late I960s, an important development has been the flourishing of "local" theatre in Hawai'i during the past generation that, as Dennis Carroll explained, is designed specifically for residents rather than tourists and is written by residents; is usually set in Hawai'i; and employs Pidgin (Hawaiian Creole English), Hawaiian language, or other "local" or indigenous performance forms, such as mele (Hawaiian song and chant) and hula (2000, I23-I24). Since I97I, the local theatre movement has centered around Kumu Kahua Theatre in Honolulu, which has been a keen supporter of and primary venue for Kneubuhl's stage plays, incorporating her work as part of its core repertory since the mid-r980s (Mattos 2002).

Furthermore, the effects of postcolonial politics of representation on the configuration and the social role and responsibilities of the museum are reflected in, and engendered by, Kneubuhl's living history programs, with their critical reappraisal of the public presentation of indigenous peoples and their heritage, and their experimentation with alternative pedagogies and means of conveying these histories and identities. Notably, this is a move that also revises certain "living history" practices, acknowledging that many reenactments elsewhere have functioned to reinforce conservative representations and uphold dominant national narratives. Kneubuhl's general engagement in "a systematic analysis of coercive and disciplining modes of representation" (Kobialka 2002, 6) is in dialogue with postmodern developments in the discipline of history, with a drive toward multiple perspectives and what may be seen as a moral self-consciousness about its processes and effects. As Michal Kobialka has observed: "With the proliferation of alternative histories and local rationalities, history has acquired a new ethical dimension of needing to be aware of, and to express, the conditions under which its knowledge becomes legitimate and hegemonic" $(2002,6)$.

Such issues are especially pertinent to current debates in Pacific studies about the possibilities of productively "decentering" the practice of history in Oceania through admission of, and engagement with, more diverse models of historical understanding and vehicles for their expression (Hanlon 2003). In each of Kneubuhl's works included here, the theatrical form offers a specific discourse within which "history" can be recapitulated and perceived (Rokem 2000, xi). In contrast to conventional forms of written historiography, the plural nature of the theatrical form integrates a repertoire of primarily oral and physical modes of communication that offer alternative ways of understanding the past. As Diana Taylor observed, 
"Part of what performance and performance studies allows us to $d o$, then, is to take seriously the repertoire of embodied practices as an important system of knowing and transmitting knowledge. The repertoire, on a very practical level, expands the traditional archive used by academic departments" (2003, 26; emphasis in original). This approach, Vilsoni Hereniko argued, represents an "interdisciplinary" perspective on past events, which, unlike many forms of academic historiography, is "marked by the following characteristics: first, it puts culture and people at the center; second, it takes into account fiction as well as fact, the irrational as well as the rational; third, it gives voice to the underrepresented; fourth, it draws from sources that cut across the boundaries of disciplines; and finally, it is always open and questioning, rather than closed and final" $(2003,75)$. The remainder of this essay examines Kneubuhl's various modes of restaging Hawai'i's history during the I980s and I990s, paying attention to the ways in which the plays' literary and performance texts have functioned to stimulate new readings of the past and the present.

\section{Plays for the Theatre}

Kneubuhl's plays for the theatre are informed by a range of theatrical influences, including the epic theatre techniques of German director Bertolt Brecht, the work of British feminist playwrights Caryl Churchill and Louise Page as well as the Cuban-American dramatist María Irene Fornés, and the early work of the American playwright Sam Shepard. Significantly, Kneubuhl was encouraged to utilize Pacific material by her uncle, John Kneubuhl, a Samoan playwright and highly regarded Hollywood screenwriter who considered it his responsibility as a Polynesian artist to draw from this rich cultural resource. In these pieces, which vary in topic, treatment, and tone, Victoria Kneubuhl has felt the freedom to "interpret history through [her] own voice" (Kneubuhl, pers comm, I Oct 2007), enjoying a greater degree of artistic license and experimentation with the boundaries of theatrical realism than in the living history programs, through incorporating fictional characters; condensing events or changing chronologies; favoring direct address, multiple roles for actors, and the presence of an onstage chorus; and integrating Hawaiian language and non-naturalistic features such as song, dance, poetry, dream sequences, ritual, the supernatural, and experiments with space and time.

In pursuing a theatrical formulation that blends together indigenous performance forms and Western theatrical frameworks, Kneubuhl has 
realized Chris Plant's model of a "Pacific theatre": an "amalgam of Western and Island traditions" that is not only useful for keeping indigenous cultures living but also relevant for portraying life as influenced by Europeans $(1973,58,59)$. Plant's model is similar to what Christopher Balme recognized in postcolonial theatre throughout the world and called "syncretic theatre" (I999, I). This process, where "culturally heterogeneous signs and codes are merged together," works against the European worldview and its impulse to homogenize, streamline, and make "pure" (Balme I999, I, 8). By employing techniques that work against normative realism and the illusory qualities that encourage passive spectatorship, Kneubuhl has denaturalized extant historical narratives and Western cultural representations while foregrounding indigenous ways of knowing and seeing in her incorporation of Hawaiian concepts and materials. As cultural products that negotiate between Western and Oceanic aesthetic and epistemic frameworks, Kneubuhl's plays are consciously critical formations that select, adapt, and reinvent-reconstituting the old in the context of the new, and adapting the new, demonstrating "local ways of doing history: ways of history that have always been with us, ways that are reemerging and being transformed in their reemergence, and new ways that appropriate existing technologies from Oceania and beyond in selective, subversive, and complicated manners" (Hanlon 2003, 2I).

Within a larger context of Pacific playwriting, Kneubuhl is not alone in her efforts to recalibrate received histories through the avenue of indigenous theatre. Beginning in the late r960s to mid-r970s, a new wave of politically motivated indigenous drama developed in several different regional sites at approximately the same time. While some mutual awareness existed, this early output appears not to have been the result of artistic collaboration between Island communities; postcolonial Pacific drama has flourished to varying degrees in different places, stimulated by broader influences such as changing social and political climates in decolonizing societies, immigration patterns and demographic changes, the rise of indigenous sovereignty and national independence movements, the establishment of supporting infrastructures such as regional universities (offering resources for training and performance), and concomitant literary developments, as well as the influence of particular educators, practitioners, and theatre companies at the local level. A great deal of this work, taking a range of forms from short playlets and agitprop performance to more formal theatrical pieces and community theatre, ${ }^{3}$ is characterized by a resistance to dominant social structures and attendant cultural 
representations; beyond incisive social commentary, many plays have also sought to make more palpable aesthetic, social, or political interventions.

Consequently, it is perhaps no surprise that despite the diversity of topics treated by Pacific playwrights, a significant number of plays are preoccupied with a critical engagement of aspects of the region's past, especially the circumstances of its colonial histories. To offer some selected examples: Several Māori playwrights in Aotearoa/New Zealand, such as Harry Dansey, Hone Kouka, Briar Grace-Smith, and Apirana Taylor, have interrogated various moments in the nation's development, posing pressing questions about the place of indigenous identity in the national imaginary, as part of a theatrical tradition tied intimately to the pursuit of tino rangatiratanga (self-determination). Historical revisionism on the Māori stage finds an ambitious expression in Witi Ihimaera's Woman Far Walking (2000), which presents an overarching view of New Zealand society since the signing of the Treaty of Waitangi from the perspective of the Māori woman Tiri, named for the treaty, and an allegory of the Māori people under colonization. This long-term approach to tracing a national or cultural history also defines Kanak playwright and politician Jean-Marie Tjibaou's Kanaké, a I975 play that was instrumental in catalyzing the Kanak independence movement in New Caledonia (Dobbelaere and Tjibaou 2006), and The Old Stories: A Play About the History of Vanuatu by the influential community theatre organization, Wan Smolbag (Dorras and Walker I99I). Myth as a model of historical understanding is another thread that runs through many of these plays. The revival of indigenous language and culture has been part of this historiographic project in several Pacific communities; an important figure is Peter Onedera in Guam, whose work in English and Chamorro has often featured historical themes. Finally, it is important to note that such plays are formulated not only in response to external colonizing forces; playwrights in Fiji, for instance, have turned to the historical record to help address the aftermath of repressive indigenous nationalism, as seen in the compelling postcoup retrospectives To Let You Know, performed in 1997 (Thomas 2002) and Ferringhi, performed in 1993 (Mishra 2001). ${ }^{4}$

Victoria Kneubuhl, then, is part of a wider movement within the Pacific, but of all these playwrights, she is the one who has developed the most sustained relationship between theatre and historiography and-while it does not characterize all of her work-has experimented most consistently with historical drama as a political and pedagogical tool. The variety of her dramaturgical approaches, the generic breadth of her engagement, and 
the material impact of her work on its broader social sphere mark her as an exemplary playwright in this regard, and suggest that her work warrants particular attention in this context.

\section{The Conversion of Ka'ahumanu}

Kneubuhl's most well known and widely produced play, The Conversion of Ka'ahumanu, which was first performed in 1988, treats the complex encounter between Native Hawaiians and American Protestant missionaries in the early nineteenth century. This cross-cultural moment was rendered even more pivotal by the historical chance that the arrival of the first missionaries in 1820 occurred only months after Ka'ahumanu (c I768-I 832)-kuhina nui (queen regent) and favorite wife of the late King Kamehameha I-had broken the kapu system (structure of privileges and taboos), fracturing the religious, social, and political order. This coincidence, along with Ka'ahumanu's conversion to Christianity in I 825, dictated Hawai'i's fortunes to a considerable extent, both in terms of the choice of Christian religion as a system to replace the abolished order, and the implications of that decision for the consolidation of the missionaries' status and that of their descendants and compatriots (Osorio 2002, II-I3). The Conversion of Ka'ahumanu is an intriguing place to start in the context of this article because the project began as a living history enactment that grew into a stage play. As an interpreter at the Mission Houses Museum in a scenario set in I83I, Kneubuhl embodied the character of Hannah Holmes (reinvented as Hannah Grimes in the play) and interacted for two years with the woman who played the role of missionary wife Sybil Bingham. Possibly because of its particular genesis, Conversion has the most realistic formal framework of Kneubuhl's plays for the theatre, with a greater reliance on documentary content. The play calls for simple staging, flexible playing areas, and a rejection of elaborate sets in favor of basic objects as focal points.

The Conversion of Ka'ahumanu attempts to convey the complexities of a nodal point of cultural and epistemological transition. In this play Kneubuhl has avoided rigid dichotomies between Hawaiian and foreigner, old and new, and attendant value judgments; she is instead invested in examining the contradictions, adjustments, and equivocations that comprise the social relations of encounter and change. The play's action unfolds through the individual perspectives of five women, using the personal and the interior as prisms through which broader social institutions and processes are refracted. Most of the play's scenes are set in the characters' 
homes, while domestic chores and leisure activities form the background action, and cultural conflict and adaptation are manifested through each character's fears, aspirations, prejudices, trials, and faith. The play's allfemale cast operates as an ensemble protagonist, with each woman pursuing her own journey to create a rich texture of "multilayered conversions" throughout the play (Usui 2004, 92). Sybil Bingham has to reconcile her own personal limitations with her Christian ideals; fellow missionary wife Lucy Thurston begins to overcome her racist attitudes after her ordeal with breast cancer; the hapa-haole (part-Hawaiian, part-white) woman, Hannah Grimes, is faced with the decision between Christian baptism and Western education on the one hand, and a life with her American lover on the other; and Pali undergoes the humiliation of public recognition as kauā (a despised class), turning to the Church for release from discrimination within the Hawaiian class structure. Each of these journeys is tied together with the simultaneously personal and political narrative of Ka'ahumanu's journey toward Christian conversion as she struggles with making the right decision for her country at a difficult time. In this respect, as Helen Gilbert observed of the play, "Kneubuhl's approach to historical events, both narratively and performatively, thus poses an implicit challenge to the imperial habit of selecting as history the public deeds of so-called great men and presenting them under the guise of ideological neutrality" (200I, 365). Gilbert's comments are especially pertinent given the characters in Kneubuhl's drama, as missionary scholars such as Sybil's husband Hiram Bingham were some of the first Westerners to historicize Hawai'i and Hawaiians, centralizing their own careers in the process.

Structurally, Kneubuhl has condensed her considerable historical material into a series of vignettes that take place over the five-year period between the missionaries' leaving the United States and Ka'ahumanu's decision to be baptized. Although these episodes advance in chronological sequence, the specific passage of time is marked indistinctly, with the emphasis less on constructing a linear, "factual" historical chronicle than on pinpointing concentrated moments that crystallize and hold up for critical judgment a number of historical intra- and cross-cultural interactions and attitudes. These moments are sometimes emphasized by Kneubuhl's technique of having the actors break the "fourth wall" and address the audience directly. In this manner, Kneubuhl's selection, organization, and presentation of material owes a significant debt to Bertolt Brecht's dramaturgical approaches. In describing how the theatrical event is constituted in the Epic theatre, Brecht used the example of a witness to a traffic 
accident: "the point is that the demonstrator acts the behaviour of driver or victim or both in such a way that the bystanders are able to form an opinion" about the event (I992, I2 I). Taking up this idea, Freddie Rokem explained, "The notion of performing history emphasizes the fact that the actor performing a historical figure on the stage in a sense also becomes a witness of the historical event. As a witness the actor does not necessarily have to strive toward complete neutrality or objectivity in order to make it possible for the spectators, the 'bystanders' in the theatre, to become secondary witnesses, to understand and, in particular, 'to form an opinion' about the forces which have shaped the accidents of history ... mak[ing] it possible for the spectators to see the past in a new or different way" $(2000,9)$. In taking this approach, Kneubuhl has worked to bring about such a transformation in her audiences by constructing them as active participants in the play's meaning-making processes.

Despite the play's reliance on documentary records, Kneubuhl has frequently changed chronologies and has incorporated fictional elements to help foreground the play's social messages, demonstrating how invention can be employed to excavate different historical "truths." For example, Lucy's account of her unanesthetized mastectomy, delivered in a powerful monologue with harrowing immediacy in the present tense (Kneubuhl 2002, 69-70), is historically documented "fact" (dramatized from Lucy's letter to her daughter), but it did not take place until some thirty years after the play's action, when Lucy was almost sixty years old (Thurston I 882, I $68-I 75)$. Its inclusion in the earlier time frame not only provides dramatic impetus for Lucy to conquer her racial prejudice but also serves as a lesson about the strength derivable from sincere faith, the hardships faced by early missionary women and their tenacious responses, and the social expectations of middle-class American women of the period. Perhaps, as Gilbert suggested, it also functions as a symbolic representation of the harmful and pervasive effects of the "cancer' of imperialism" (200I, 365). Similarly, as part of a broader theme in the play that explores the ideological and material pros and cons of Christianity, Kneubuhl created a fictionalized scene between Sybil and Hannah in which Hannah's reading from the Bible is juxtaposed with Sybil's narration of Hannah's divergence from the path to baptism. The irony emerges from the fact that both women draw from the Bible to determine their life paths, but Hannah, significantly, reads passages from the Old Testament's Song of Songs (Kneubuhl 2002, 62-63), and it is her affinity with the Song's sentiments that justifies her decision to leave the mission and take up with her lover, Jones. 
The Song of Songs is something of an anomaly in the scriptures because of its erotic nature and the fact that it "tells no sacred history, makes no theological nor moral points, and does not mention God" (Matter I990, 49), and Hannah interprets the text literally, without the allegorical rendering imposed by Christian exegetes. Through Kneubuhl's use of one of the most controversial components of the Bible as a documentary intertext, the Bible is revealed as a contradictory text compiled over time and across cultures. The scene thus questions the Bible's status as a historical and moral authority, while simultaneously revealing the very real vagaries of cross-cultural interpretations and applications of Christian teaching.

These critical and dramaturgical strategies are usefully brought to bear on what may be read as the play's central concern: the treatment of Ka'ahumanu and "the transmogrification of religion into political and cultural strategy" (Carroll 2000, I35). This is a sensitive issue, given Ka'ahumanu's controversial status as a historical figure, with audiences holding strong opinions about whether her decisions amounted to a salvation or a betrayal of Native Hawaiian culture (Howes 2002, xix). Kneubuhl's concentrated, personalized approach avoids blanket readings of Ka'ahumanu, allowing audiences to evaluate the choices available to her and to understand her dilemma over how to "steer our canoe" through the "storm, blown every which way by the white men," who are like "hungry sharks" and "hoards of caterpillars, hiding their hunger to devastate the land," dangerous in their voracious capitalist and imperialist desires (Kneubuhl 2002, 37, 76). Ka'ahumanu's conflicts and equivocations are heightened by their portrayal through powerful departures from realism, such as the kanikau (mourning chant) in the Hawaiian language, in which Ka'ahumanu laments the cultural changes and her own lack of direction, and her surreal fever sequence, in which interior conflicts are manifested by a series of voices from her subconscious, berating her for abandoning the old gods and for causing the death of her people (Kneubuhl 2002, 47-50). In Kneubuhl's configuration Ka'ahumanu is neither exonerated nor condemned but is shown as a complex person in an untenable situation, seeking a pragmatic compromise between native and foreign, old and new ways, in the face of unbridled Western immigration. As she explains to the audience in her final testimony: "I do not look to the past with contempt, but seek to preserve the ways that were good, uniting them with what is good of this new world, that comes to us, now" (Kneubuhl 2002, 76; emphasis in original). 


\section{Emmalehua}

In contrast to The Conversion of Ka'ahumanu, Emmalehua and Ola Nā Iwi are primarily concerned not with reappraisals of Hawaiian historical figures but with the retrieval and restoration of aspects of Hawaiian cultural history in a twentieth-century society dominated increasingly by Western influences. Whereas Gilbert noted the strategy in several of Kneubuhl's works of looking at Hawai'i's history from the point of view of legendary Hawaiian women (200I, 364), in these two plays the central perspective is that of an (otherwise) ordinary woman rendered special because of a particular sensitivity or experience that (re)opens a pathway to the cultural past. Emmalehua and Ola Nā Iwi, moreover, engage Hawaiian spirituality through metaphysical objects or entities that have been lost but return and reassert themselves as unresolved issues in the plays' presents. Consequently, these plays operate in multiple time registers, developing more fluid relationships between their past and present moments. Compared to Conversion, both plays demonstrate a greater artistic freedom in their portrayal of historical events, personages, and traditions and are marked by a more inventive experimentation with theatrical syncretism, deploying Native Hawaiian performance forms and cultural practices as key thematic as well as formal devices.

The initial version of Emmalehua was Kneubuhl's first full-length play, originally completed in 1984 but revised substantially in $1996 . .^{5}$ The play's principal setting is Honolulu in I95 I, the Hawai'i of Kneubuhl's childhood and a time of rapid change- a postwar climate of Americanization and imminent statehood accompanied by a burgeoning tourism industry that was marked in complement by a devaluation and suppression of Hawaiian culture. Several of the play's characters represent a generation of Hawaiians who have grown up dislocated from their heritage, encouraged to disavow the past in favor of performing both the "American" identities being advocated as the basis of Hawai'i's future and exoticized versions of Hawaiian culture repackaged for transient outsiders.

In a similar mode to Conversion, Kneubuhl's approach is to register this broader milieu through the dynamics of a single local family: tensions between the past and the future and between Hawaiian and American culture are manifested in and through marital rifts, sibling rivalries, and subjective conflicts. The central figure is Emma, a young Hawaiian woman chosen as a small child by her kupuna (grandmother) to carry the 
spiritual and aesthetic knowledge of the hula, but who has attempted to repress this knowledge in adulthood under the pressure to assimilate an American-style suburban bourgeois normativity. She is encouraged to do this by her husband, Alika, whose experiences fighting in the US Army have fueled his desire to pursue an American Dream of "prosperity" and "progress," in contrast to "the dark ages of Hawai'i's past" (Kneubuhl 2002, 90). Kneubuhl has created dramatic tension on various levels by positioning Emma's individual struggle alongside the experiences of other characters who represent the inevitable fate of Hawaiian cultural forms if traditions are not maintained, as well as those who point to the longerterm implications of US expansionism. In the absence of Emma's practice, the art of hula in the family is represented by Emma's part-Chinese half sister, Maelyn, who dances a kitschy version for tourists at a nightclub in Waikîki. Maelyn's performance is situated in the broader context of commercialized hula and Hollywood images of Hawai'i of the I950s-reinforced in the play by the spectatorial responses of Maelyn's and Alika's gauche friends, who rave about their experience of a tawdry, transplanted Hawai' $i$ in a Las Vegas casino revue and applaud the hula danced by male lifeguards in drag (Kneubuhl 2002, 95, I3 I ). Hawaiian scholar and activist Haunani-Kay Trask used the metaphor of the prostitute to condemn the commercial hula as "smutty and salacious," stripped of spiritual significance, with the dancer, like the prostitute, "complicitous in her own commodification" (I999, I44). It is perhaps no accident that Maelyn is portrayed as a person with shallow cultural and social values and as a licentious woman who behaves like her unfaithful mother and eventually seduces Alika. In counterpoint Kneubuhl has introduced the Cheyenne character, Adrian Clearwater, whose Native American perspective offers a salutary lesson about the negative implications of US territorial acquisition and cultural assimilation. In one telling exchange, Alika's secure sense that statehood will "be a great equalizer. Things will be more equal," is rendered ambivalent by Clearwater's wry rejoinder, "You're talking to someone who grew up on a reservation" (Kneubuhl 2002, I09). At the same time, for Emma, Clearwater represents an affirmative link to an indigenous culture that reinvigorates her desire to reclaim her own personal history and cultural heritage.

Of all Kneubuhl's plays, Emmalehua engages most directly the relationship between personal memory and collective cultural history. Emma's personal loss can be seen to resonate with a larger cultural condition of the period, in which colonial discourse had rendered Hawaiian cultural 
memory no longer natural or continuous, leading to a lack of cohesion. In disavowing her Hawaiian identity in order to assume the image of the colonizer, Emma is caught between two worlds, unable to identify with Hawaiian or American culture; instead she inhabits a destructive double consciousness that threatens to fracture her completely. Emma's individual crisis is exacerbated by the fact that the kapu that she was placed under as a child was never lifted before her grandmother's death, leaving an incomplete cultural rite and unresolved personal history. In adulthood, Emma is tormented by the return of the unfinished business of the past, manifested in fragmented form as recurring dreams, traumatic visions, and feelings of being suffocated, drowned, folded, and pushed down in her everyday existence. These psychic states are powerfully embodied by an onstage chorus, which, in a series of surreal and vertiginous sequences, articulates her unspoken feelings and sometimes threatens to physically overwhelm her.

The past's persistent resurgence is also marked by the meaningful return of objects from Emma's own childhood and Hawaiian cultural tradition: the ancient lei hoaka (boar tusk and woven human hair necklace), last worn by Emma's grandmother, and the wooden image of the hula goddess, Laka. Ultimately, it is Emma's recognition and deployment of these auratic objects that opens the route to retrieval and redemption. From a performance perspective, just as Emma is haunted, so is the theatrical stage haunted by these "material ghosts" (Sofer 2003, 3) from the Hawaiian cultural past. Importantly, Kneubuhl's introduction of these charged material objects to "bear witness" on the stage allows them to function as an alternative form of rendering history that draws attention to experiential and spiritual modes of understanding. The theatre is the ideal venue for the framing and display of these objects-as-history; as Marvin Carlson argued, "this ghostly quality, this sense of something coming back in the theatre" is a fundamental aspect of stage performance, which is characterized by repetition and recycling, and thus functions as a "repository of cultural memory" $(2003,2)$. As stage properties, the relics are resurrected and reinvigorated in performance, drawing on theatre's capacity to "bring dead images back to life" (Sofer 2003, 3). The objects mobilized in performance function as potent visual and affective signifiers with the capacity to absorb and transmit meaning and to evoke powerful memories and responses in the audience, representing a history that is living, vibrant, and accessible.

Emmalehua turns on Emma's reclamation of her repressed memories and knowledge of hula, renewing her obligation to the past and her ances- 
tors and pursuing the possibility of an alternative future characterized by wholeness and connection. Emma's final decision not to "erase the past and hand [Alika] the future" is symbolized by the return of the spirit of Emma's kupuna, who helps Emma to complete the unfinished rite and to revive and perform the hula rituals: gathering the mountain greenery, building an altar to Laka, and delivering a traditional Hawaiian chant to Laka. These ceremonies are followed by Emma's dance, which is accompanied by the chorus dressed for traditional hula (Kneubuhl 2002, I34, I35-I36). The performance of the hula within the frame of the theatrical performance offers a compelling syncretic moment that foregrounds and reinforces the memorial and embodied link to Hawaiian cultural tradition.

According to Jeanette Malkin, in postmodern theatre "the rooted autonomous self, the subject-in-consciousness, is no longer available"; gone, too, is the "faith in memory to capture truth, find origins, and heal" (I999, 7). Emmalehua, however, retains the potential for healing and for redemption and the hope of a personal and cultural coherence through a renewed connection with Hawaiian culture. Kneubuhl's play upholds the possibility of connecting to a more coherent sense of identity through a return to, and reclamation of, the values of a consistent indigenous culture-values that persist over time and space and sustain the displaced minority in an oppressive colonial milieu. Notably, at its conclusion, Emmalehua does not uphold an exclusivist or static cultural vision: Emma's promise to pass her knowledge on to Maelyn stakes a claim in cultural maintenance based on openness and shared wisdom. Kneubuhl's play undertakes an important task in pointing to the importance of Hawaiian performance and cultural traditions, and in reiterating the link between past and present that persists despite colonial intervention. In so doing, it weaves an affirmative counter strand into the dominant discourse of Hawai'i's teleological progress toward US nationalism.

Emmalehua's focus on looking to the past and the ancestors for solutions to present problems, and implicit questioning of Western notions of future-oriented historical progression, exemplify a Hawaiian perception of time. ${ }^{6}$ As historian Lilikalā Kame eleihiwa explained: "It is interesting to note that in Hawaiian, the past is referred to as Ka wa mamua, or 'the time in front or before.' Whereas the future, when thought of at all, is Ka wa mahope, or 'the time which comes after or behind.' It is as if the Hawaiian stands firmly in the present, with his back to the future, and his eyes fixed upon the past, seeking historical answers for present-day dilemmas" (I994, 22-23; italics in original). This orientation has a European 
analogy in Walter Benjamin's famous Angel of History, who also faces the past with his back to the future. However, unlike Benjamin's critique of historicism, which posits history as "one single catastrophe which keeps piling wreckage upon wreckage and hurls it in front of [the Angel's] feet" as he is blown back violently, out of control, by the storm of progress (1968, 257), the Hawaiian perspective takes a positive view, looking back to a past which is "rich in glory and knowledge" (Kame'eleihiwa I994, 23). As Jonathan Kamakawiwo'ole Osorio affirmed: "We face the past, confidently interpreting the present, cautiously backing into the future, guided by what our ancestors knew and did" $(2002,7)$. While acknowledging the existence of, and the potential to be overwhelmed by, the traumas and destructive failures of the past cast as "progress," Kneubuhl's plays and programs consistently demonstrate a confidence in a wisdom of the past that is generous and sustaining, that may indeed be able to "awaken the dead, and make whole what has been smashed" (Benjamin I968, 257), and that is available to provide direction in the present.

\section{Ola Nā Iwi}

As in Emmalehua, Ola Nà Iwi (The Bones Live) takes a topical issuethe repatriation and reburial of Native Hawaiian remains-and focuses it through the experience of a young woman, Kawehi, who takes responsibility for doing justice to the past in the present. While the main narrative strand concerns the protagonist's reappropriation of Hawaiian bones from a German museum and their eventual reinterment in their homeland, Ola Nā Iwi is Kneubuhl's most complex play, interweaving aspects of Hawaiian language and ritual alongside elements of detective story and ghost story, shifts in register between tragedy and farcical comedy, temporal and spatial shifts, and experimentation with metatheatrical themes and techniques. The play, furthermore, presents Kneubuhl's broadest engagement with the "use and abuse" of history, moving beyond a consideration of a particular historical event, period, or practice to examine issues of historical representation in a wide range of cultural and institutional manifestations.

Of Kneubuhl's plays for the theatre, Ola Nā Iwi develops the most fluid temporality, creating the sense of a history that is not discrete but is accessible and continues to impact the present in tangible ways. ${ }^{7}$ The most powerful image through which the past and the present are brought into simultaneity onstage is the persevering spirit of Nanea, the owner of the bones, who in many respects represents a more developed version of 
the kupuna figure in Emmalehua. As the play's title indicates, in Hawaiian culture, the mana and spirit of a person are believed to reside with their bones, even after death (Purnell I993, 216). In this manner, Nanea forges a link between the I 83 os and the I990s, although her long journey accompanying her displaced bones has been a traumatic one; her spirit has been "forced to wander, unhappy and restless, never finding its way to the ao 'aumākua, the realm of the ancestors, never finding home" (Kneubuhl 2002, I75). Rokem remarked that historiographic performance may feature supernatural figures who operate as "victimized witness[es], belonging to the metaphysical sphere, whose function, just like the intervention of the gods in the classical theatre through the deus ex machina, is to set things right again" $(2000,206) .{ }^{8}$ As an unsettled sprit, Nanea is just such a witness, whose central task is to "set things right again" by taking proper care of her remains. She achieves this objective through a series of dei ex machinis: compelling Kawehi to rescue her from the museum storage facililty in Berlin; intervening in one of the many switch scenes that characterize the play's comic action by swapping her own bones with a fake set of stage-prop bones to avoid their destruction; and initiating the construction of a kā'ai, a sennit casket for her bones (Rose I992, 2), which she and Kawehi weave in tandem. The weaving of the kā'ai-which, Kawehi claims, "No one knows how to make" (Kneubuhl 2002, I76)—is another example of a "lost" knowledge that is retrieved from the kūpuna (ancestors) and brought back to enrich the present, and it is foregrounded as a performative rite within the larger play.

An important means by which Nanea seeks to reconcile the wrongs of the past is testifying about her experiences. As Rokem argued, appropriately, "The cathartic processes activated by the theatre performing history are more like a 'ritual' of resurrection, a revival of past suffering, where the victim is given the power to speak about the past again" (2000, 205). The stakes are raised for the other characters (and, potentially, for theatre audiences) when it is revealed that Nanea is in fact Kuini Liliha (c I802I 839), a beloved ali'i who served as royal governor of O'ahu from I829I 83 I and-in a circumstance that links back to Kneubuhl's concerns in Conversion-was famously at odds with the Protestant mission and with Ka'ahumanu. In the play, Kneubuhl has reimagined a strand of Hawai'i's history, reinventing a remarkable posthumous history for Liliha that is at once bold and tragic, beginning with the switching of her body for someone else's before her memorial service at Lahaina, her secret burial according to traditional Hawaiian precepts, and then the discovery of her remains 
by "foreign men" who commodified her bones and "traded them for so much money" (2002, 2II). The cathartic quality of Liliha's testimony is important in the context of this play, given that ultimately her resurrection is not for the purpose of a future revival but of a laying to rest: "just a peaceful place to lie, undisturbed, in my own native land" (Kneubuhl 2002, 199). The character of Liliha gives a voice to the dead witnesses, standing up for those whose remains have been desecrated or displaced.

Elsewhere in the play, parts of Liliha's testimony are treated with a lighter tone: while waiting for the kā'ai to be woven, Liliha takes a "day job" as a living history interpreter in downtown Honolulu, telling her own story to twentieth-century tourists (2002, I73-I 75, 208-209). These scenes, which embed a performance-about-history in a performance-abouthistory, point to a metatheatrical quality that is another key approach adopted throughout Kneubuhl's play. Ola Nā Iwi can be read as a conscious meditation on, and critical exploration of, the practice and politics of cultural and historical representation, using "theatre" as a metaphor and a material strategy for raising critical questions about truth, illusion, authenticity, staging, display, authority, interpretation, and identity.

In structuring Ola Nā Iwi, Kneubuhl has augmented the usual "theatrical" features of the detective story-its role playing, disguises, deceptions, and revelations-by making her characters part of a theatre troupe and thus crafting a self-reflexive play in which actors play actors, and props appear as props. The Berlin museum's "research and exhibit" mandate (Kneubuhl 2002, I 5 I) suggests that Liliha herself has at times been constructed as an "actor" of sorts—or, at least, a prop-in the museum's stage-managed displays, presented as a scientific curiosity, as art, and as an example of "Hawaiian history." Liliha's display is echoed in the play performed by the "Aulama theatre troupe at the Berliner Festival, which offers another representation of Hawaiian history: a counter-canonical rendering of Shakespeare's Hamlet set in precontact Hawai'i, in which the various realistic props (including the set of fake bones) are presented as examples of what Christopher Balme has elsewhere called "staged authenticity" $(2007,47-48)$.

Significantly, the choice of Hamlet as a source text, with its prevalent tropes of ghosting, return, and metatheatricality, resonates implicitly with the general action in the remainder of Kneubuhl's play. More specifically, Kneubuhl's engagement with theatre history through the integration of Shakespearean allusions also serves both to illumine characters' motives and emotional states and to highlight the stakes of the play. ${ }^{9}$ In act 2 , 
scene 6 , for example, most of the main characters attend a costume party to celebrate Hamlet's Berlin tour. Kawehi's decision to come as Ophelia underscores her sense of desperation about the course of action she has taken, which now threatens to spiral out of control. Kawehi's remark, "And pansies, that's for thoughts" (Kneubuhl 2002, 204), paraphrases a line from Ophelia's mad speech in act 4, scene 5 of Hamlet, shortly prior to Ophelia's death by drowning, and is delivered at the same point in the play as Kawehi's admission, "I've crossed the line where what I think doesn't count for much" (Kneubuhl 2002, 204). These Shakespearean resonances thus inject a tension and pathos into the scene's more playful atmosphere, emphasizing Kawehi's fraught entrapment between cultural politics, the law, and her own sense of justice. In the same scene, Shakespearean analogies are employed for more comically satiric ends, with the German investigator, Gustav, attired as Bottom the Ass from A Midsummer Night's Dream. The conscious citation of comic characters and tropes, however, such as the self-referential portrayal of the Players as Elizabethan clowns, also deepens the rationale for Ola Nā Iwi's generic choices; whereas comedy might seem a strange fit for the subject matter the play treats, the Shakespearean "wise fool" figures point to comedy's potential to enact trenchant cultural commentary.

Theatrical awareness, similarly, is evident in the historical sequencesjuxtaposed with the action in contemporary Berlin and Honolulu-that treat testimonies from phrenologists, grave robbers, and acquisitive museum owners from the late nineteenth and early twentieth centuries. One such example is the play-within-a-play presented by the traveling showman the Reverend Dr Pinchbottom who (along with his delectable assistant, Miss Ida) fraudulently advertises the practice of phrenology and recruits men to desecrate "heathen" graves in order to supply human specimens to scientists and museum curators. Dr Pinchbottom's show represents the diffusion of scientific discovery into the popular sphere, channeled through the gaudy discourse of vaudeville and the rhetoric of the snake-oil salesman (Kneubuhl 2002, I70-I72). The tacky theatricality of this presentation enables Kneubuhl to point to the dubious nature of the whole enterprise of phrenology and bone collecting, stripping it of its scientific respectability and exposing its methods as cheap and underhand.

Further issues regarding the representation of Hawaiian history and identity are taken up in the exchanges between Kawehi and Pua Ho'olale, Kawehi's supervisor at her museum job in Honolulu. Pua's reinvention as a "Native Hawaiian" after a life lived as "Kelly Brooks" highlights 
the performative nature of cultural identity; in this case, Pua's cultural performance is marked by hypocrisy, her professed advocacy for Hawaiians masking unabashed self-interest. In one scene, Pua and Kawehi clash over the politics of historical representation, with Pua ordering Kawehi to perform the "correct" kind of Hawaiian history in Kawehi's exhibit about a historic heiau (temple) at Wailele by giving an account that idealizes the Hawaiian past but downplays the site's religious significance so that Pua can profit when the site is turned into a resort (Kneubuhl 2002, I68-I69). Here, the play offers a critical appraisal of different approaches to Hawaiian cultural advancement, incorporating a lesson about ways to approach the past and its relationship to the present in which Kawehi's "healthy anger [that] can help us to make changes" is seen as the better alternative to Pua's anger, which is "poisoning her" (Kneubuhl 2002, 203).

Whereas Ola Nā Iwi is Kneubuhl's most consciously theatrical play, it incorporates serious moral lessons about our responsibilities to the past, the present, and the future. As Liliha advises Kawehi before she is finally laid to rest: "It's up to you, the living. You carry the past and the future" (Kneubuhl 2002, 215). While utilizing distinct dramaturgical strategies, all three of Kneubuhl's plays for the theatre have an investment in looking to the past in order to rethink the present and the future in productive ways, a motif developed in different forms in Kneubuhl's living history programs.

\section{Living History Programs}

Kneubuhl's living history programs have several elements in common with her stage plays, but differ markedly in that "by necessity these pieces place a greater emphasis on history and information rather than art" (Kneubuhl 1999). Kneubuhl described these works as having a "hybrid form," occupying a space in between the "living history" reenactments sometimes featured at museums and historic sites, and theatrical works. Staged in museums or related historical venues, the programs often feature museum employees and other members of the community alongside or instead of professional actors, and, while shaped by artistic interpretation, they rely heavily on oral and written documentary sources for their form and subject matter. Kneubuhl's experiences as a living history performer helped her appreciate what a powerful teaching tool performance can be for helping people understand the past and its impact on the present; its dynamism, immediacy, and use of affect "provide a platform for debating 
controversial issues" and "reinforce the message that history happened to real people, like them" (Kneubuhl, pers comm, I Oct 2007).

The programs draw strongly on the form and stagecraft of documentary theatre and its ties to agitprop theatre and theatre-in-education, and they demonstrate many of the precepts of "critical pedagogy," derived from the work of Paulo Freire (2003), encouraging spectators to identify and resist prejudicial cultural myths and to work to transform oppressive social relations. Although present in all of Kneubuhl's historiographic works, these programs perhaps illustrate most effectively the concept of the actor as a "hyper-historian" (Rokem 2000, I3), forming a connective link between the "then" of the past and the "now" of the theatrical event and enabling us to comment on and draw conclusions about the past. In this way, the audience members are also turned into historians of sorts, and the performance text might itself be read as a historical document, a "valuable device for understanding the world in which it exists and to which it speaks" (scholar Thomas Michael Croak, quoted in Dawson I999, I7).

"January, I 893," "Trial of a Queen," and "The Annexation Debate" were, Kneubuhl explained, "written to commemorate pivotal events in Hawaiian history which resulted in the loss of the Hawaiian Nation as an independent, self-governing entity" (I999). Despite her interest in other historical periods, for Kneubuhl the overthrow of the Hawaiian monarchy is "the rock in the pond" that impacted most profoundly the lives of her family and her community (Kneubuhl, pers comm, I Oct 2007). Of the programs, which offer alternatives to dominant historical narratives of US nation building, Kneubuhl wrote: "They were meant to be learning tools to introduce a history which until recently was not discussed or taught in the mainstream" and are "purposefully written from a particular point of view," because "It is my belief that being informed about the political events of our collective past will greatly aid us in making important decisions about our collective future" (I999). Each program employs different techniques and approaches to its material, yet all of them undertake important cultural work in advancing Hawaiian self-determination and, significantly, have demonstrated art's social potential by actively affecting public policy in Hawai'i.

\section{"January, I 893"}

w. o. sмiтh: They'll get over it. In time, everyone will get over it and forget. SANFORD DOLE: Will they? I wonder.

"January, I893," page 9I 
"January, I893" represents what is most likely Hawai'i's most ambitious and politically effective theatrical endeavor, a work that Dennis Carroll considered "to date the most significant recent local-Hawaiian theatre event to dramatize the loss felt in the present by the 'crimes' of the past" (2000, I40). "January, I 893" was commissioned by the Hawaiian sovereignty education organization Hui $\mathrm{Na}$ 'auao for performance during the 'Onipa'a (Steadfast) Centennial Observance, an event sponsored by the Hawai'i State Legislature and the Office of Hawaiian Affairs to mark the one hundredth anniversary of the overthrow of Queen Lili'uokalani (I 838 -I9I7) on I 7 January I 893 by a group of white missionary descendants with the support of US troops. In offering a critical appraisal of these tumultuous events, Kneubuhl was aware that the material was controversial but believed that she was providing a "valuable community service," given that "the Hawaiian sovereignty movement is important contemporary history in the making" (Kneubuhl and Strazar 1994, I3). The performance of "January, I893" was remarkable for its scale and scope: a fifteen-hour running time over three days ( I 5-I 7 January I993); its large cast, augmented by the input of various community groups; its framing within a series of commemorative and activist events; its charged presentation at a number of sites on the 'Iolani Palace grounds and in the adjacent historical district in what is now the capitol district in downtown Honolulu; and its huge number of spectators, estimated at over 20,000.

The epigraph on the manuscript of "January, I893" reads, "We will not forget." Kneubuhl's statement is significant in light of Ernest Renan's observation, "Forgetting, I would even go so far as to say historical error, is a crucial factor in the creation of a nation, which is why progress in historical studies often constitutes a danger for [the principle of] nationality" (I990, II). A key aspect of the critical pedagogy that underpins "January, I 893 " is the drive to redress national amnesia both by interrogating hegemonic versions of Hawaiian history that uphold and celebrate the values of US expansionism and reinforce entrenched social iniquities, and by advancing an alternative national narrative that sutures the memory of a legitimate, sovereign Hawaiian nation with present identities and selfdetermination efforts.

A central strategy by which Kneubuhl's programs encourage critical thinking and cultural action is to lend the past relevance and immediacy in the present. One example is the interpellation of the spectators as part of a special community, as active participants who belong to, maintain, 
and thus have a responsibility to the history being performed. In a move that demonstrates Kneubuhl's synthesis of historical fact and dramatic embellishment, the nineteenth-century action is framed by a storyteller, an archetypal character named Kupunawahine (ancestor woman), who invites the audience to travel back to "hear a story of the past" that is "our story, your story." Situating the events of I 893 within a longer Hawaiian history, Kupunawahine emphasizes the continuity between the past and the present: the past is "Here in our blood, in our bones, here in our ancestors that we carry on our back"- those ancestors who "left to us a bridge that we might return and visit and learn" (Kneubuhl I993, 2). Kupunawahine's welcome offers an empowering message: whereas cultural legacies may have been submerged by colonial discourse, they are not lost or broken but are lived and embodied and can be taken up in the present. Identification with the past record is also effected through the device of "The People," a small collection of royalists (real and fictional) of Native Hawaiian, Chinese, Greek, and German backgrounds, representing an ethnic and socioeconomic cross-section of late nineteenth century Hawaici. The People are fully embedded in the dramatic action but function as traveling witnesses throughout the performance, giving audiences a focal point by commenting on and contextualizing the action in the different scenes and by tying the various events to their own experiences and memories. The relevance and immediacy of the past in "January, I 893 " is further heightened by the site-specific staging. Here, buildings and locations familiar to spectators in downtown Honolulu, such as 'Iolani Palace, the Coronation Stand, the Royal Burial Mound, Ali'iolani Hale, and the Old Customs Building, form a central part of the mise-enscène (stage setting) for the production and are reinscribed, resonating with their past significance. This general technique, which Gary Dawson read as one of the "authentifying sign systems" of documentary theatre ( 1999,3 I), serves to create a feeling of verisimilitude and tangibility of encounter, bringing audiences "back to the scene" and conflating the past and present in the moment of performance.

A pivotal aspect of Kneubuhl's revisionism is her positive characterization of Queen Lili'uokalani. All three living history programs seek to restore Native Hawaiian agency by redressing racist and infantilizing nineteenth-century stereotypes of the last Hawaiian queen, which portrayed her as a dangerous revolutionary, savage, immoral, and unfit to rule (Silva 2004, I66, I73-I80). Throughout the performance, the dignity, grace, courage, and magnanimity of the queen is juxtaposed with the avarice, 
manipulation, and scheming rhetoric of the coup makers, who validate their enterprise by seeing it as an extension of the acts of the "brave men" of I776 and the Civil War (Kneubuhl I993, 3I). "January, I 893" makes explicit Lorrin Thurston's expedient translation of the queen's address regarding the deferment of a new constitution in order to validate the overthrow of the monarchy; although the program makes it clear that the queen says that she will defer the presentation of the constitution "to some future date," Thurston and his colleagues deliberately translate the ambiguous Hawaiian phrase "ua keia mau la" as "in a few days," with Smith calling out, "Make sure Judd translates it that way," as a justification for immediate action to protect American interests (Kneubuhl I993, 35, 37). While Kneubuhl's program deflates the heroism of the white oligarchy, it also offers some variation and invests some characters with a greater degree of complexity. Sanford Dole's ambivalent attitude toward taking power of the Provisional Government, for instance, is highlighted in the altercation with his hanai (adopted) daughter, Lizzie Low, who berates him for selling out the Hawaiians (Kneubuhl I993, 89-90).

The compelling finale of "January, I 893 " also involves an amalgam of the documentary record and Kneubuhl's own artistic intervention, culminating in the queen's concession speech at 'Iolani Palace, which was delivered under protest but undertaken for the protection of her people. The speech, taken directly from the historical document, is extended by Kneubuhl's rousing exhortations to the Hawaiian people: "Hold fast to that pride and love you have for your heritage and your country. Yes, your country! . . . never give up-to seek through peaceful, political means to unite as one people" and to "regain our rightful heritage and rightful government" (1993, I02-103; emphasis in original). This moving and emancipatory message for the present and the future, witnessed in 1993 by I0,000 spectators (half of the estimated overall audience) is exemplary of how "January, I 893" as an educational performance project utilizes techniques of critical pedagogy for social transformation. As museum theorist Margaret Lindauer explained, this approach employs both a language of critique-identifying, analyzing, and deconstructing hierarchical social relations-and a language of hope-fueling a strategic desire to change those structures $(2007,3 \mathrm{IO})$. In turn, citizens contributed to the process begun by the performance of "January, I 893 ": "It stirred debate in the media and prompted public discussions of both the historical and current issues that surround sovereignty" (Kneubuhl and Strazar I994, I4). Significantly, a number of new bills on Hawaiian issues and sovereignty were introduced 
in the state legislature after the performance, and according to Kneubuhl and her coauthor Marie D Strazzar: "The senator reported that he thought the introduction of those bills came in response to the overwhelming interest in the centennial activities and, in particular, the historical events that were portrayed during the course of the pageant" (I994, I4).

\section{"Trial of a Queen" and "The Annexation Debate"}

I conclude this broad examination of Kneubuhl's work with a brief discussion of two shorter programs, "Trial of a Queen: I895 Military Tribunal" (I995) and "Ho'ohui "Āina: The Annexation Debate" (I998). Both programs operate on a more modest level than "January, I893" and are designed for smaller audiences and performance spaces, but they are important complements to that larger performance in their examination of events leading up to the United States' annexation of Hawai'i and in their use of critical pedagogy for progressive social purposes. "Trial of a Queen" was sponsored by the Hawai'i Committee for the Humanities and developed for the Judiciary History Center in Honolulu as part of a larger centennial living history program about the events of 1895 to which a range of historians and other scholars contributed. The program covers the trial of Queen Lili'uokalani by a military tribunal (6-8 February I 895) following an unsuccessful royalist attempt to overthrow the Provisional Government, established in I 893. Despite a lack of evidence that the queen was aware of the planned countercoup, she was found guilty of misprision of treason and forced to abdicate, ending any hope of the restoration of the monarchy. "The Annexation Debate," developed in consultation with historians Noenoe Silva and Tom Coffman, was prepared for the Governor's Committee in the summer of 1998 to mark the centennial of the US annexation of the Hawaiian Islands. In the program, emphasis is placed on Native Hawaiian resistance to annexation, especially the formulation of the 1897 anti-annexation petition signed by the majority of Hawaiians; the performance thus makes accessible in English certain sources that otherwise exist only in Hawaiian. Significantly, the performance, staged at the Bishop Museum in Honolulu, accompanied an important disclosure of historical information: the first public display of the 556-page petition, located by Silva in the US National Archives. This new knowledge changed the way the centennial was celebrated and how people thought about themselves and their pasts. They realized that the kūpuna were not passive victims of colonization who stood by while their 
nation was taken but that they had fought passionately and strategically for their rights (Silva 2004, 3-4).

The "trial" and "debate" structure of these two programs, which emphasizes the making of a case, presentation of evidence, cross-examination, interpretation, and evaluation, might be seen to offer a demonstration of the historiographic process itself. The subject matter, moreover, which pitches native histories against hegemonic colonial versions, offers an explicit representation of historical revisionism at work. In presenting multiple perspectives on the "same" historical event, these programs offer audiences a more complex view of the past, highlighting dialogism, contradictions, and lacunae, and foregrounding a sense of "history" as not fixed or final but in process, open to question, negotiation, and reconstruction. Importantly, specific juxtapositions allow for broader interpretive moments. In "Trial of a Queen," the cases of the royalists and the Provisional Government are presented in such a way that makes clear the queen's innocence as well as the broader workings of political power that contrive her conviction as a means to an end. In "The Annexation Debate," many different documents and testimonies relating to the antiannexation struggle are presented, not just to prove the righteousness of the cause, but to confirm the widespread nature of anti-annexation feeling, which reverberated locally and internationally.

In both programs, an important device-reminiscent of Erwin Piscator (1963) and Bertolt Brecht (1992) -is the self-conscious interlocutor, who serves as a guide or conductor through the material (Dawson I999, 32), and who provides a distancing effect, making explicit the apparatus of theatrical presentation and the craft of the actor in order to frame the performance as an educational tool and to stimulate critical responses to the program's content. ${ }^{10}$ In "Trial of a Queen," this role is played by Maka, a fictional farmer from Kāne'ohe who has come to watch the trial; as one of the rural maka'äinana (common people) he represents a voice largely absent from the official historical record. The actor playing Maka deliberately demarcates different frames of performance by introducing himself as a role player, explaining the purpose and strategies of the living history program, and outlining the critical work required of the audience, before undergoing the transformation into character (Kneubuhl I995, I). Throughout the program, Maka occupies a liminal position between the audience and the other actors in the "historical realm," commenting on and elucidating the content of the trial, and posing searching questions 
about the social role of the law and its relationship to justice (Kneubuhl I995, 6I).

Related techniques are present in "The Annexation Debate," in which the protagonists-key nineteenth-century anti-annexation activists James Keauiluna Kaulia, elected leader of the Hui Aloha 'Āina, and Emma 'A'ima Nāwahī, editor of the newspaper Ke Aloha Aina and leader in the Women's Patriotic League-function as narrators and teachers, introduced via the device of having been mysteriously "brought back" from the past to tell their stories of resistance. Kneubuhl's technique (also seen elsewhere) of resurrecting historical witnesses in a metaphysical mode is here given a specific political purpose, framed as a neglected history that, as Emma explains, "will help you to understand who you are and where you come from," and that stands in contrast to the accounts of the "usurpers" who "explained away" annexation, "as did many historians who came afterwards" (Kneubuhl I998, 2, 32). On the stage, relating personal memory and collective history, the actors embody and augment the moment of disclosure afforded by the exhibition of the petition, engendering identification and emotional engagement and contributing to the spectators' own understanding of their place in history. Rokem acknowledged this restorative potential of historical performance, arguing, "The theatre constantly strives to affirm such impulses for liberation expressed by the actors, who through their creative energies are able to stand up for the dead" (2000, 97-98). The ritualized closing scene of "The Annexation Debate" cements the empowering quality of this history of resistance. Emma and James approach the audience holding lei that symbolize the gift of the knowledge of the past, telling the people, "Remember us, our names written down, each name of every aloha 'āina." The gift bequeathed by those in the past is something "fashioned out of love, aloha-aloha for our "aina, for the lahui, and for each other" and is "Never bought and never sold" but "lives forever, embracing us all" (Kneubuhl I998, 35).

Staging works such as "Trial of a Queen" and "The Annexation Debate" as educational programs in museum environments foregrounds the programs' critical engagement with the museum's role in producing and disseminating knowledge. Implicit here is an awareness of the museum as an authoritative cultural institution (much like the theatre in other contexts) that too often upholds society's dominant values and power structures (Peers 2007, I72). Performing living history programs of this nature encourages the museum to function as a forceful site for combating racism 
and prejudice, fostering social recognition and empowerment, and contributing to greater social equity through the representation of difference and diversity (Peers 2007, I79).

Throughout her career, Kneubuhl has been committed to using theatrical performance in its various forms to interrogate historical injustices, hegemonic versions of historical "truth," and characterizations of Hawaiian culture that erase or overwrite indigenous experience and epistemologies, while offering restorative messages and, in some instances, stimulating efforts that bring about material social change. Kneubuhl's historiographic performances demonstrate how "history is a repository of possibilities that are living options for future action," offering, in the interface between performer and spectator, "experiences of meaning making and imagination that can describe or capture fleeting intimations of a better world" (Dolan 2005, I 47, 2). While it remains for another study to provide the in-depth critical attention that Kneubuhl's work undoubtedly deserves, this overview of Kneubuhl's pedagogy and playwriting highlights a range of dramaturgical strategies employed to engage the cultural past through theatrical performance and contributes to a broader dialogue about the ways in which theatre functions actively within Hawai'i and the broader postcolonial Pacific.

I AM GRATEFUl to Victoria Nalani Kneububl for taking the time to discuss her work with me during my visit to the University of Hawai' i in fall 2007. I acknowledge the assistance of Dennis Carroll and Kumu Kahua Theatre, and I extend my thanks to William Wortman for access to unpublished manuscripts in the Native American Women Playwrights Archive, Miami University, Ohio. I have also benefited from the insightful comments offered by the two anonymous reviewers of this article.

\section{Notes}

I These are the terms Kneubuhl has used to distinguish the two genres in her "Notes to Living History Programs" (1999), reiterated in our personal discussion at the University of Hawai'i at Mānoa on I October 2007.

2 Parenthetical dates in this paragraph refer to the years the plays and living history programs were completed and first performed. Citations for any other plays mentioned in this article refer to the date of publication or manuscript copy- 
right (if unpublished). All page citations to Kneubuhl's published plays in this essay are from the anthology Hawai ${ }^{i}$ Nei: Island Plays (Kneubuhl 2002).

3 The term "agitprop" refers to political theatre; from "agitation" + "propaganda."

4 For a fuller discussion of this topic, see Looser 2009.

5 This discussion is based on the revised version.

6 This particular viewpoint is shared by several Polynesian cultures; see, for instance, Māori cosmology, in which events from the past appear in front of one (ki mua) as one walks backward into the future (kei muri).

7 In her discussion of the play, Sammie Choy has usefully employed the concept of the "palimpsest" to describe how previously overwritten elements of cultural memory surface beneath more recent inscriptions and assume an intricate interplay $(2008,2$ I0).

8 The Latin phrase "deus ex machina" refers to a plot device whereby a problem is suddenly and abruptly solved by the sudden introduction of a god (deus) or other new character, ability, or object. "Dei ex machinis" is the plural form.

9 I am indebted to one of the anonymous reviewers of this article for prompting me to think more carefully about how the use of Shakespeare informs our understanding of characters in the play.

Io Although Kneubuhl did not originally include such a character in the script of "January, I 893," the logistics of staging the program in "real time" over three days made an interlocutor necessary to suture the action and elaborate its messages to the steadily increasing crowds. This role was represented by Daniel Logan, a royalist supporter and journalist from I 893 (played by the late Glen Grant).

\section{References}

Balme, Christopher

I999 Decolonizing the Stage: Theatrical Syncretism and Post-colonial Drama. New York: Oxford University Press.

2007 Pacific Performances: Theatricality and Cross-Cultural Encounter in the South Seas. New York: Palgrave-Macmillan.

Benjamin, Walter

I968 Illuminations: Essays and Reflections. Translated by Harry Zohn and edited and introduced by Hannah Arendt. New York: Schocken.

Brecht, Bertolt

I992 Brecht on Theatre: The Development of an Aesthetic. Edited and translated by John Willett. New York: Hill and Wang.

Carlson, Marvin

2003 The Haunted Stage: The Theatre as Memory Machine. Ann Arbor: University of Michigan Press. 
Carroll, Dennis

2000 Hawai'i's "Local” Theatre. TDR: The Drama Review 44 (2): I $23-152$.

Choy, Sammie

2008 The Bones Perform: Ola Nā Iwi and the Viability of Memory. In Signatures of the Past: Cultural Memory in Contemporary Anglophone North American Drama, edited by Marc Maufort and Caroline De Wagter, 209-22 I. Brussels: Peter Lang.

Dawson, Gary Fisher

I999 Documentary Theatre in the United States: An Historical Survey and Analysis of Its Content, Form, and Stagecraft. Westport, ст: Greenwood.

Dobbelaere, Georges, and Jean-Marie Tjibaou

2006 Kanaké: A Three-Act Play. Translated by Roy Benyon. Suva: Pacific Writing Forum, University of the South Pacific.

Dolan, Jill

2005 Utopia in Performance: Finding Hope at the Theater. Ann Arbor: University of Michigan Press.

Dorras, Jo, and Peter Walker

I99I The Old Stories: A Play About the History of Vanuatu. Port Vila: Australian South Pacific Cultures Fund.

Freire, Paulo 2003 Pedagogy of the Oppressed. New York: Continuum.

Gilbert, Helen, editor 200 I Postcolonial Plays: An Anthology. London: Routledge.

Gilbert, Helen, and Joanne Tompkins I996 Postcolonial Drama: Theory, Practice, Politics. London: Routledge.

Hanlon, David

2003 Beyond "the English Method of Tattooing": Decentering the Practice of History in Oceania. The Contemporary Pacific I 5:I9-40.

Hereniko, Vilsoni

2003 Interdisciplinary Approaches in Pacific Studies: Understanding the Fiji Coup of I9 May 2000. The Contemporary Pacific I 5:75-90.

Howes, Craig

2002 Introduction. Hawai'i Nei: Island Plays, ix-xxviii. Honolulu: University of Hawai'i Press.

Ihimaera, Witi

2000 Woman Far Walking. Wellington: Huia.

Kame'eleihiwa, Lilikalā

I994 Native Land and Foreign Desires: Pehea Là E Pono Ai? Honolulu: Bishop Museum Press. 
Kneubuhl, Victoria

I993 January, I893. Typescript. Native American Women Playwrights Archive, Miami University, Ohio.

I995 Trial of a Queen: I 895 Military Tribunal. Typescript. Native American Women Playwrights Archive, Miami University, Ohio.

I998 Ho'ohui 'Āina: The Annexation Debate. Typescript. Native American Women Playwrights Archive, Miami University, Ohio.

I999 Notes to Living History Programs. Unpublished memo, unnumbered pages. Native American Women Playwrights Archive, Miami University, Ohio.

2002 Hawai'i Nei: Island Plays. Introduction by Craig Howes. Honolulu: University of Hawai'i Press.

Kneubuhl, Victoria, and Marie D Strazar

I994 January I893: The Overthrow of the Hawaiian Monarchy Relived in History. History News 49 (I): I 2-I4.

Kobialka, Michal

2002 Historical Archives, Events and Facts: History Writing as Fragmentary Performance. Performance Research 7 (4): 3-I I.

Lindauer, Margaret

2007 Critical Museum Pedagogy and Exhibition Development: A Conceptual First Step. In Museum Revolutions: How Museums Change and Are Changed, edited by Simon J Knell, Suzanne MacLeod, and Sheila Watson, 303-3 I 4. London: Routledge.

Looser, Diana

2009 Remaking Pacific Pasts: A Comparative Study of Contemporary Historiographic Theatre from Oceania. $\mathrm{PhD}$ dissertation, Cornell University.

Malkin, Jeanette

I999 Memory-Theater and Postmodern Drama. Ann Arbor: University of Michigan Press.

Matter, E Ann

I990 The Voice of My Beloved: The Song of Songs in Western Medieval Christianity. Philadelphia: University of Pennsylvania Press.

Mattos, Justina

2002 The Development of Hawai'i's Kumu Kahua Theatre and Its Core Repertory: The "Local” Plays of Sakamoto, Lum, and Kneubuhl. PhD dissertation, University of Hawai'i, Mānoa.

Mishra, Sudesh

200I Ferringhi: A Play in Seven Lilas. In Beyond Ceremony: An Anthology of Drama from Fiji, edited by Ian Gaskell, 332-39I. Suva: Institute of Pacific Studies and Pacific Writing Forum. 
Osorio, Jonathan Kamakawiwo'ole

2002 Dismembering Lāhui: A History of the Hawaiian Nation to 1887. Honolulu: University of Hawai'i Press.

Peers, Laura

2007 Playing Ourselves: Interpreting Native Histories at Historic Reconstructions. Lanham, MD: Altamira/Rowman and Littlefield.

Piscator, Erwin

I963 The Political Theatre. New York: Avon.

Plant, Chris

I973 Theatre and the South Pacific. Mana Annual of Creative Writing I:5860.

Purnell, Nanette Napoleon

I993 Oriental and Polynesian Cemetery Traditions in the Hawaiian Islands. In Ethnicity and the American Cemetery, edited by Richard E Meyer, I93-22 I. Bowling Green, OH: Bowling Green State University Press.

Renan, Ernest

I990 What is a Nation? In Nation and Narration, edited by Homi K Bhabha, 8-22. London: Routledge.

Rokem, Freddie

2000 Performing History: Representations of the Past in Contemporary Theatre. Iowa City: University of Iowa Press.

Rose, Roger G

1992 Reconciling the Past: Two Basketry Kā'ai and the Legendary Lìloa and Lonoikamakahiki. Honolulu: Bishop Museum Press.

Silva, Noenoe K

2004 Aloha Betrayed: Native Hawaiian Resistance to American Colonialism. Durham, NC: Duke University Press.

Sofer, Andrew

2003 The Stage Life of Props. Ann Arbor: University of Michigan Press.

Taylor, Diana

2003 The Archive and the Repertoire: Performing Cultural Memory in the Americas. Durham, NC: Duke University Press.

Thomas, Larry

2002 To Let You Know and Other Plays, edited by Ian Gaskell. Suva: Pacific Writing Forum.

Thurston, Lucy Goodale

I882 Life and Times of Mrs. Lucy G. Thurston, Wife of Rev. Asa Thurston, Pioneer Missionary to the Sandwich Islands. Ann Arbor: S C Andrews.

Trask, Haunani-Kay

I999 From a Native Daughter: Colonialism and Sovereignty in Hawai'i. Revised edition. Honolulu: University of Hawai'i Press. 
Usui, Masami

2004 Hawai'i as a Motherland in Victoria Nalani Kneubuhl's Plays. Doshisha Daigaku Eigo Eibungaku Kenkyu (Doshisha University Studies in English Language and Literature) 77 (3): 87-II9.

\section{Abstract}

During the past twenty years, Hawaiian dramatist and museum educator Victoria Nalani Kneubuhl has become established as one of the foremost playwrights working in the contemporary Pacific. Since the mid-I980s, a dominant strand of Kneubuhl's oeuvre has involved a critical examination of Hawai'i's colonial history, using various forms of theatrical performance to interrogate historical injustices and characterizations of Hawaiian culture that erase or overwrite indigenous epistemologies, offering restorative models and, in some instances, stimulating efforts that bring about material social change. This paper surveys six of Kneubuhl's historiographic works produced during the I980s and I990s, highlighting varied dramaturgical strategies employed to engage the cultural past in order to address contemporary concerns. The discussion distinguishes two broad theatrical genres arising from Kneubuhl's training and work experience: historical "plays for the theatre," which incorporate fictional or fantastic elements and are designed for repeated performance within the aesthetic and commercial frame of amateur or professional theatre production; and her "living history programs," site- and occasion-specific performances based more directly on documentary sources and developed in consultation with historians, with a stricter pedagogical purview and a tendency toward a more realist style of presentation. This overview of Kneubuhl's plays and programs foregrounds the important cultural interventions effected by her work during the last two decades, and contributes to an investigation of the various uses of performance in helping to construct indigenous histories in Oceania, while engaging in a broader dialogue about the ways in which theatre functions actively within the postcolonial Pacific.

KEYWORds: Victoria Kneubuhl, Hawai'i, Pacific drama, historiography, indigenous histories 